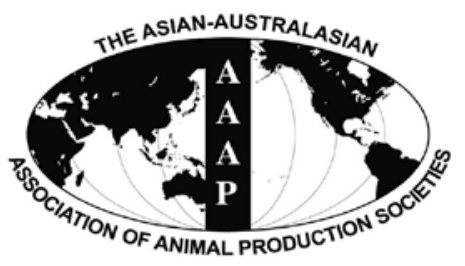

Asian-Aust. J. Anim. Sci.

Vol. 25, No. $1: 66$ - 74

January 2012

www.ajas.info

http://dx.doi.org/10.5713/ajas.2011.11158

\title{
Effect of Exogenous Fibrolytic Enzyme Application on the Microbial Attachment and Digestion of Barley Straw In vitro
}

\author{
Y. Wang ${ }^{1{ }^{*}}$, J. E. Ramirez-Bribiesca ${ }^{1,2}$, L. J. Yanke ${ }^{1}$, A. Tsang ${ }^{3}$ and T. A. McAllister ${ }^{1}$ \\ ${ }^{1}$ Agriculture and Agri-Food Canada, Lethbridge Research Centre, Lethbridge, Alberta, Canada, T1J4B1
}

\begin{abstract}
The effects of exogenous fibrolytic enzymes (EFE; a mixture of two preparations from Trichoderma spp., with predominant xylanase and $\beta$-glucanase activities, respectively) on colonization and digestion of ground barley straw and alfalfa hay by Fibrobacter succinogenes S85 and Ruminococcus flavefaciens FD1 were studied in vitro. The two levels (28 and $280 \mu \mathrm{g} / \mathrm{ml})$ of EFE tested and both bacteria were effective at digesting NDF of hay and straw. With both substrates, more NDF hydrolysis ( $<<0.01)$ was achieved with EFE alone at 280 than at $28 \mu \mathrm{g} / \mathrm{ml}$. A synergistic effect $(\mathrm{p}<0.01)$ of $F$. succinogenes S85 and EFE on straw digestion was observed at 28 but not $280 \mu \mathrm{g} / \mathrm{ml}$ of EFE. Strain $R$. flavefaciens FD1 digested more $(\mathrm{p}<0.01)$ hay and straw with higher EFE than with lower or no EFE, but the effect was additive rather than synergistic. Included in the incubation medium, EFE showed potential to improve fibre digestion by cellulolytic ruminal bacteria. In a second batch culture experiment using mixed rumen microbes, DM disappearance (DMD), gas production and incorporation of ${ }^{15} \mathrm{~N}$ into particle-associated microbial $\mathrm{N}\left({ }^{15} \mathrm{~N}\right.$-PAMN) were higher $(\mathrm{p}<0.001)$ with ammoniated ( $5 \% \mathrm{w} / \mathrm{w}$; AS) than with native (S) ground barley straw. Application of EFE to the straws increased ( $<<0.001)$ DMD and gas production at 4 and $12 \mathrm{~h}$, but not at $48 \mathrm{~h}$ of the incubation. EFE applied onto $\mathrm{S}$ increased $(\mathrm{p}<0.01){ }^{15} \mathrm{~N}-\mathrm{PAMN}$ at $4 \mathrm{~h}$ only, but EFE on AS increased $(\mathrm{p}<0.001){ }^{15} \mathrm{~N}-\mathrm{PAMN}$ at all time points. Prehydrolysis increased $(\mathrm{p}<0.01)$ DMD from both $\mathrm{S}$ and AS at 4 and $12 \mathrm{~h}$, but reduced $(\mathrm{p}<0.01){ }^{15} \mathrm{~N}$-PAMN in the early stage $(4 \mathrm{~h})$ of the incubation, as compared to non-prehydrolyzed samples. Application of EFE to barley straw increased rumen bacterial colonization of the substrate, but excessive hydrolytic action of EFE prior to incubation decreased it. (Key Words : Exogenous Feed Enzymes, Rumen Bacteria, Straw, Ammoniation, In vitro)
\end{abstract}

\section{INTRODUCTION}

Cellulolytic microorganisms in the rumen are responsible for the digestion of fibrous plant materials in ruminants (Windham and Akin, 1984). The adhesion of these microorganisms to feed particles is essential for fibre degradation (McAllister et al., 1994). Recent studies have shown that addition of exogenous fibrolytic enzymes (EFE) increases microbial growth and production of microbial protein (Giraldo et al., 2008; Gado et al., 2009). Morgavi et al. (2004) observed that application of EFE from Trichoderma promoted adhesion of Fibrobacter succinogenes S85 to and degradation of corn silage and alfalfa hay, but not pure cellulose. Wang et al. (2001) found

\footnotetext{
* Corresponding Author : Y. Wang. Tel: +1-403-317-3498, Fax: +1-403-382-3156, E-mail: yuxi.wang@agr.gc.ca

${ }^{2}$ Colegio de Postgraduados, enlace ganaderia, Montecillo, Edo. De Mexico. Mexico.

${ }^{3}$ Centre for Structural and Functional Genomics, Concordia University; Montreal, Quebec, Canada.

Received May 27, 2011; Accepted August 5, 2011
}

that EFE increased $\mathrm{N}^{15}$ incorporation into particle associated microbial $\mathrm{N}$ and ruminal cellulolytic activity when EFE was applied onto dry feed prior to consumption but not when directly infused into fermenters. However, when EFE was applied onto silage it promoted the activity of aerobic microbes and had an adverse effect on rumen microbial $\mathrm{N}$ incorporation (Wang et al., 2002). These results suggest that hydrolytic action of EFE on feed prior to its consumption may play a role in regulating the efficacy of EFE although the mechanism is not known. The availability of EFE products targeting ruminants are increasing, but their effects on nutrient utilization have been inconsistent, possibly due to the multiple modes of action (McAllister et al., 2001; Beauchemin et al., 2003) as well as the variation of enzymatic activities among different EFE preparations.

The objectives of the present study were to examine the effect of EFE on rumen cellulolytic bacteria growth in pure culture and to evaluate the action of pre-ruminal and ruminal hydrolysis on the overall effectiveness of EFE during simulated rumen fermentation. 


\section{MATERIALS AND METHODS}

Experiment 1: Determination of different concentrations of EFE on bacterial digestion of barley straw and alfalfa hay

Digestion of barley straw and alfalfa hay by two ruminal cellulolytic bacteria, Fibrobacter succinogenes S85and Ruminococus flavefaciens FD1, without EFE supplement or with supplementation of EFE at two different concentrations was determined in an in vitro experiment.

Barley straw and alfalfa hay (5.0 kg total for each) were randomly selected from 20 large round bales at the Lethbridge Research Centre (LRC), ground through a 2.0$\mathrm{mm}$ screen and sieved using a 1.5-mm screen to collect particles between 1.5 and $2.0 \mathrm{~mm}$. The ground barley straw or alfalfa hay, $100 \mathrm{mg} / 20-\mathrm{ml}$ glass culture tubes, was sterilized at $125^{\circ} \mathrm{C}$ for $20 \mathrm{~min}$. To each tube, $5.0 \mathrm{ml}$ of modified Scott and Dehority medium (1965) that contained $5 \%(\mathrm{v} / \mathrm{v})$ clarified rumen fluid was added containing either no enzymes (control; C) or EFE preparation at $28 \mu \mathrm{g} / \mathrm{ml}$ or $280 \mu \mathrm{g} / \mathrm{ml}$ (equivalent to 1.4 and $14.0 \mathrm{~g} / \mathrm{kg} \mathrm{DM}$ of the substrates). The EFE solution was prepared using a powdered 2:1 (wt:wt) combination of xylanase and $\beta$-glucanase preparations from Trichoderma longibrachiatum (Biovance Technologies Inc., Omaha, NE, USA). The final enzyme mixture exhibited xylanase, $\beta$-glucanase, carboxymethylcellulase and amylase activities (expressed as $\mu$ g reducing sugars (RS) released/min per mg DM) of 6.87, 5.00, 3.09, and 1.90, respectively (Wang et al., 2003).

All tubes were incubated at $39^{\circ} \mathrm{C}$ for $24 \mathrm{~h}$, then inoculated with $100 \mu \mathrm{l}$ of $F$. succinogenes $\mathrm{S} 85$ or $R$. flavefaciens FD1 (LRC culture collection) which had previously been grown in modified Scott and Dehority medium containing filter paper at $39^{\circ} \mathrm{C}$ for $48 \mathrm{~h}$. Each treatment was performed in quadruplicate and parallel sets of tubes with EFE treatment without bacteria (EFE control) or bacteria without EFE (bacterial control) were also included. Upon termination of the incubation, cultures were centrifuged $\left(10,000 \times \mathrm{g}, 20 \mathrm{~min}, 4^{\circ} \mathrm{C}\right)$ and the pellet was analysed for NDF (Van Soest et al., 1991).

Additionally, cellulolytic bacteria were also incubated with straw and hay that had been pre-hydrolyzed with 28 $\mu \mathrm{g} / \mathrm{ml}$ or $280 \mu \mathrm{g} / \mathrm{ml}$ of xylanase or $\beta$-glucanase preparations from T. longibrachiatum as described above for the EFE combination. These samples were prepared for scanning electronic microscopy as described (Bae et al., 1993), viewed with a Hitachi S-570 SEM, and were photographed with digital image capture system of Kodak electron microscope.

Experiment 2: Interactions between EFE and mixed

\section{rumen microbes during barley straw digestion}

Preparation of barley straws and EFE treatments: Barley straw $(4.0 \mathrm{~kg}$ ) was randomly selected from 10 large round bales at LRC and ground through a $2.0-\mathrm{mm}$ screen and sieved with a 1.5-mm screen to collect particles between 1.5 and $2.0 \mathrm{~mm}$. After thorough mixing, ground straw (500 g) was packed in three plastic bags and treated with ammonium hydroxide to a final concentration of $5 \%$ ammonium (wt/wt, DM basis). The bags were then sealed and stored at room temperature for 1 wk before being dried at $50^{\circ} \mathrm{C}$ (AS). Ground straw (500 g) was also packed into three plastic bags and stored at room temperature (native barley straw; S). Each bag of straw (S and AS) was then subsequently prepared as following (50 g for each treatment) for the in vitro experiment: i) Control (treated with water; C): Straws were sprayed with de-ionized water at a rate of $10 \mathrm{ml} / 100 \mathrm{~g}$ straw using a single-nozzle bottle sprayer before the start of the experiment and immediately placed in 35-ml serum vials (550 mg/vial); ii) Treated with EFE (and used immediately; E): Straws were sprayed with EFE (de-ionized water solution containing $150 \mathrm{mg}$ EFE/ml) using a single-nozzle bottle sprayer before the start of the experiment and immediately weighed $550 \mathrm{mg}$ to $35-\mathrm{ml}$ serum vials. The same moisture content was maintained as the control so that the EFE applied to the straw achieved 15 $\mathrm{mg} / \mathrm{g}$ straw DM. The enzyme preparation was the same as that used in Experiment 1; iii) Pre-hydrolyzed with EFE (EP): $10 \mathrm{ml}$ of de-ionized water containing $7.5 \mathrm{mg}$ of EFE as described above was added to each $35-\mathrm{ml}$ serum vial containing $500 \mathrm{mg}$ of ground straw. The vials were incubated at $39^{\circ} \mathrm{C}$ for $24 \mathrm{~h}$, freeze-dried, and stored at $4^{\circ} \mathrm{C}$ for the in vitro experiment; iv) Washed pre-hydrolyzed biomass (i.e., pre-hydrolyzed and washed; EPW): 3.0-L flasks, each containing $100 \mathrm{~g}$ of straw and 1,500 mg EFE in $2.0 \mathrm{~L}$ of water, were incubated for $24 \mathrm{~h}$ at $39^{\circ} \mathrm{C}$. The contents were filtered with Waterman No. 1 filter paper and the liquid fraction was sampled for analysis of RS. After washing three times with de-ionized water by filtration, the pellets were freeze-dried, weighed, divided into three portions, with one portion (500 mg) weighed into 35-ml serum vial for in vitro experiment as EPW; v) Treatment EPW followed by re-application of inactivated EFE $(\mathrm{EPW}+\mathrm{AE})$ in the amount equal to that of EFE applied in treatment E: The second portion of the EPW was sprayed with autoclaved EFE-water solution using a single-nozzle bottle sprayer before the start of the in vitro experiment and immediately weighed (550 $\mathrm{mg}$ ) into $35-\mathrm{ml}$ serum vials at the same moisture content and enzyme concentration as that for E; vi) EPW followed by re-application of RS $(\mathrm{EPW}+\mathrm{RS})$ : The third portion of the EPW was applied with a mixture of glucose and xylose (50:50) in amounts equal to that found in EPW using the application method described above. Following addition of sugars, straws, $550 \mathrm{mg} / \mathrm{vial}$ 
were used immediately for the in vitro experiment.

In vitro experiment: All 12 substrates (36 preparations in total), except EP and EPW, were treated prior to the start of the batch culture incubation. Two steers with permanent rumen cannula, fed an alfalfa-grass hay diet that was formulated to meet nutrient requirements, were used as rumen fluid donors. Cattle used in this study were cared for in accordance with standards of the Canadian Council on Animal Care (CCAC, 1993). Rumen fluid was collected $2 \mathrm{~h}$ after morning feeding by straining the rumen content collected from five different locations in the rumenreticulum region through four layers of cheese cloth. Equal amounts of rumen fluid from each steer were combined and kept at $39^{\circ} \mathrm{C}$ under anaerobic condition during transportation to the laboratory. The rumen fluid was combined with a mineral buffer (Menk et al., 1979) in the ratio of 1:2 just before inoculation. As a microbial $\mathrm{N}$ marker, $\left({ }^{15} \mathrm{NH}_{4}\right)_{2} \mathrm{SO}_{4}$ was included $(0.75 \mathrm{~g} / \mathrm{L})$ in the buffered rumen fluid. The vials that contained prepared substrates were inoculated with $20 \mathrm{ml}$ of buffered rumen fluid, flushed with $\mathrm{CO}_{2}$, sealed and incubated at $39^{\circ} \mathrm{C}$ in a shaking (125 rpm) incubator. Gas production from each vial was measured using a water displacement device at 4, 12, 24 and $48 \mathrm{~h}$ of incubation. Triplicate vials (one vial from one bag of preparation) of each substrate were retrieved from the incubator at $0,4,12$ and $48 \mathrm{~h}$ of the incubation and processed to measure dry matter disappearance (DMD) and microbial $\mathrm{N}$ incorporation.

The whole culture in each fermentation vial after retrieval from the incubator was filtered through a layer of nylon cloth $(45 \mu \mathrm{m})$. The filtrate was sampled and processed for determination of VFA (Wang et al., 2002). The digestion residue retained on the nylon cloth was rinsed thrice with phosphate buffer ( $\mathrm{pH}$ 7.4). The buffer contained (g/L) $\mathrm{Na}_{2} \mathrm{HPO}_{4} 7 \mathrm{H}_{2} \mathrm{O}$ (5.95), $\mathrm{KH}_{2} \mathrm{PO}_{4}$ (0.76) and $\mathrm{NaCl}$ (7.2). The residue after final washing was then dried at $55^{\circ} \mathrm{C}$, weighed and analyzed for ${ }^{15} \mathrm{~N}$ as described by Wang et al. (2002).

\section{Calculations and statistical analysis}

Digestion of NDF in Experiment 1 was calculated by the difference of the NDF before and after incubation with bacteria, and was corrected by the blank control. Dry matter disappearance in Experiment 2 was calculated by the weight difference of the substrate prior to and after incubation with mixed rumen microbes. Rumen microbial attachment in Experiment 2 was estimated by measuring the amount of ${ }^{15} \mathrm{~N}$ in digestion residues, which represented particleassociated microbial ${ }^{15} \mathrm{~N}\left(\mathrm{PAM}^{15} \mathrm{~N}\right)$.

Data from Experiment 1 was analyzed as a complete randomized design and data from Experiment 2 as $2 \times 6$ factorial design by analysis of variance using the MIXED procedure of SAS (2007), with individual tube/vial as the random factor. The model used for analysis of time-course data (repeated measures) in vitro included time and time $x$ treatment interaction. When these effects (time or timex treatment interaction) were significant, the means of the treatments were compared at each time point. The significance of differences among treatments was tested using LSMEANS with the PDIFF option.

\section{RESULTS}

\section{Experiment 1}

Both levels of EFE and both bacterial species were effective at digesting NDF from alfalfa hay and barley straw (Table 1). With both substrates, degradation of NDF increased linearly $(\mathrm{p}<0.01)$ with increasing EFE application rates from 28 to $280 \mu \mathrm{g} / \mathrm{ml}$. The bacterial species did not differ in their capacity to degrade NDF from straw, but $R$. flavefaciens had a greater capacity $(\mathrm{p}<0.01)$ to digest hay than did F. succinogenes. A synergistic effect $(\mathrm{p}<0.01)$ of $F$. succinogenes and enzyme in digestion of straw was observed at $28 \mu \mathrm{g} / \mathrm{ml}$ (as the NDF disappearance was greater for this bacteria supplemented with EFE than the sum of the bacteria and EFE alone), but not at $280 \mu \mathrm{g} / \mathrm{ml}$. $R$. flavefaciens digested more hay and straw with $280 \mu \mathrm{g} / \mathrm{ml}$

Table 1. Effect of a mixture of xylanase and $\beta$-glucanase preparations on disappearance of NDF (mg/g) from alfalfa hay and barley straw during incubation with Fibrobacter succinogenes S85 and Ruminococus flavefaciens FD1

\begin{tabular}{lrrrr}
\hline & \multicolumn{4}{c}{ Enzyme concentration $(\mu \mathrm{g} / \mathrm{ml})$} \\
\cline { 2 - 4 } & 0 & 28 & 280 & SEM \\
\hline Alfalfa hay & & & 74.1 & 1.88 \\
$\quad$ Uninoculated & 0.0 & 33.4 & 64.9 & 1.79 \\
$\quad$ F. succinogenes & 48.0 & 50.6 & 215.0 & 1.84 \\
$\quad$ R. flavefaciens & 133.6 & 131.9 & 90.6 & 1.72 \\
Barley straw & & & 123.7 & 2.05 \\
$\quad$ Uninoculated & 0.0 & 25.6 & 120.8 & 1.98 \\
F. succinogenes & 68.9 & 182.8 & \\
$\quad$ R. flavefaciens & 93.1 & 103.7 & & \\
\hline
\end{tabular}

SEM = Standard error of means. 
enzyme ( $<<0.01)$ than with 0 or $28 \mu \mathrm{g} / \mathrm{ml}$.

Scanning electronic microscopy showed that preincubation of substrate with enzyme enhanced subsequent $R$. flavefaciens colonization of alfalfa hay and barley straw (Figures 1 and 2). The enzyme mixture that contained mainly $\beta$-glucanase activity promoted colonization of substrates to a greater extent than the preparation that possessed mainly xylanase activity. Only scattered F. succinogenes cells were observed attached on straw and alfalfa hay for all samples, but there was evidence of digestion pits that suggested that cells had detached from the substrate (data not shown).

\section{Experiment 2}

Interactions among treatments and between treatment and incubation time were observed $(\mathrm{p}<0.05)$ and therefore data were analyzed and presented at each incubation time point (Tables 2, 3 and 4). Overall, ammoniation enhanced $(p<0.01)$ ruminal fermentation of barley straw. At each incubation time point (4, 12, and 48 h), GP, DMD, concentration of total VFA and $\mathrm{PAM}^{15} \mathrm{~N}$ were all higher $(p<0.001)$ with AS than with S. The effects of EFE on these ruminal fermentation products, however, depended on straw type (S or AS) and EFE application (substrate preparation) method.

Compared to $\mathrm{C}$, application of EFE to S immediately prior to incubation (treatment $E$ ) increased $(p<0.01)$ GP at 4 $\mathrm{h}$ and DMD at 4, 12 and $48 \mathrm{~h}$, whereas application of EFE to AS increased $(\mathrm{p}<0.01) \mathrm{GP}$ and DMD at 4 and 12 , but not at $48 \mathrm{~h}$ incubation (Table 2). Similarly, compared to C, enzymatic pre-hydrolysis increased $(\mathrm{p}<0.01)$ GP from both $\mathrm{S}$ and $\mathrm{AS}$ at 4 and $12 \mathrm{~h}$ and DMD at 4,12 and $48 \mathrm{~h}$.

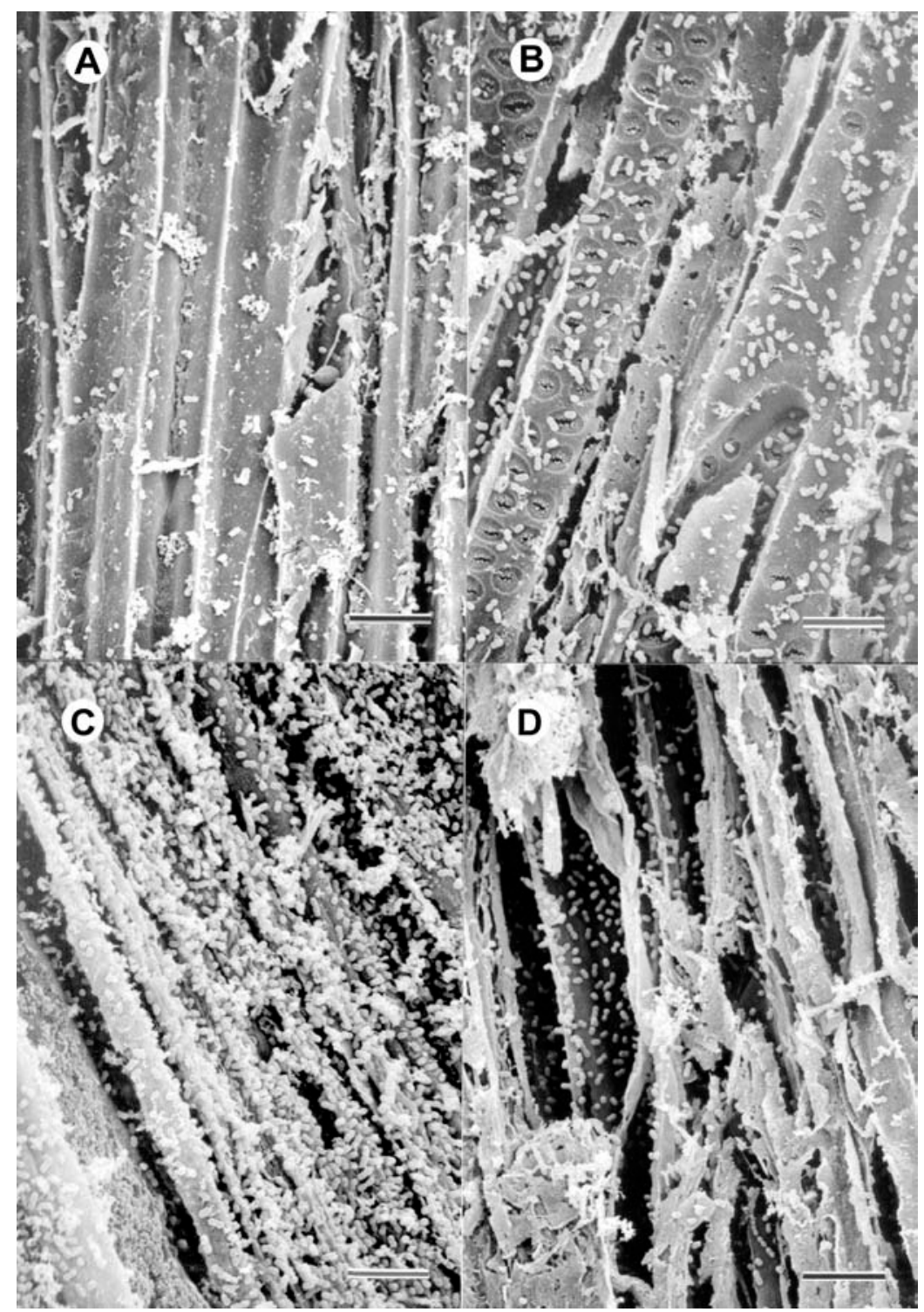

Figure 1. Scanning electron micrographs of alfalfa hay incubated for $48 \mathrm{~h}$ with Ruminococcus flavefaciens in the presence of A) no enzyme, B) $28 \mu \mathrm{g} / \mathrm{ml} \beta$-glucanase, C) $280 \mu \mathrm{g} / \mathrm{ml} \beta$-glucanase and D) $280 \mu \mathrm{g} / \mathrm{ml}$ xylanase. Bars $=10 \mu \mathrm{m}$. 


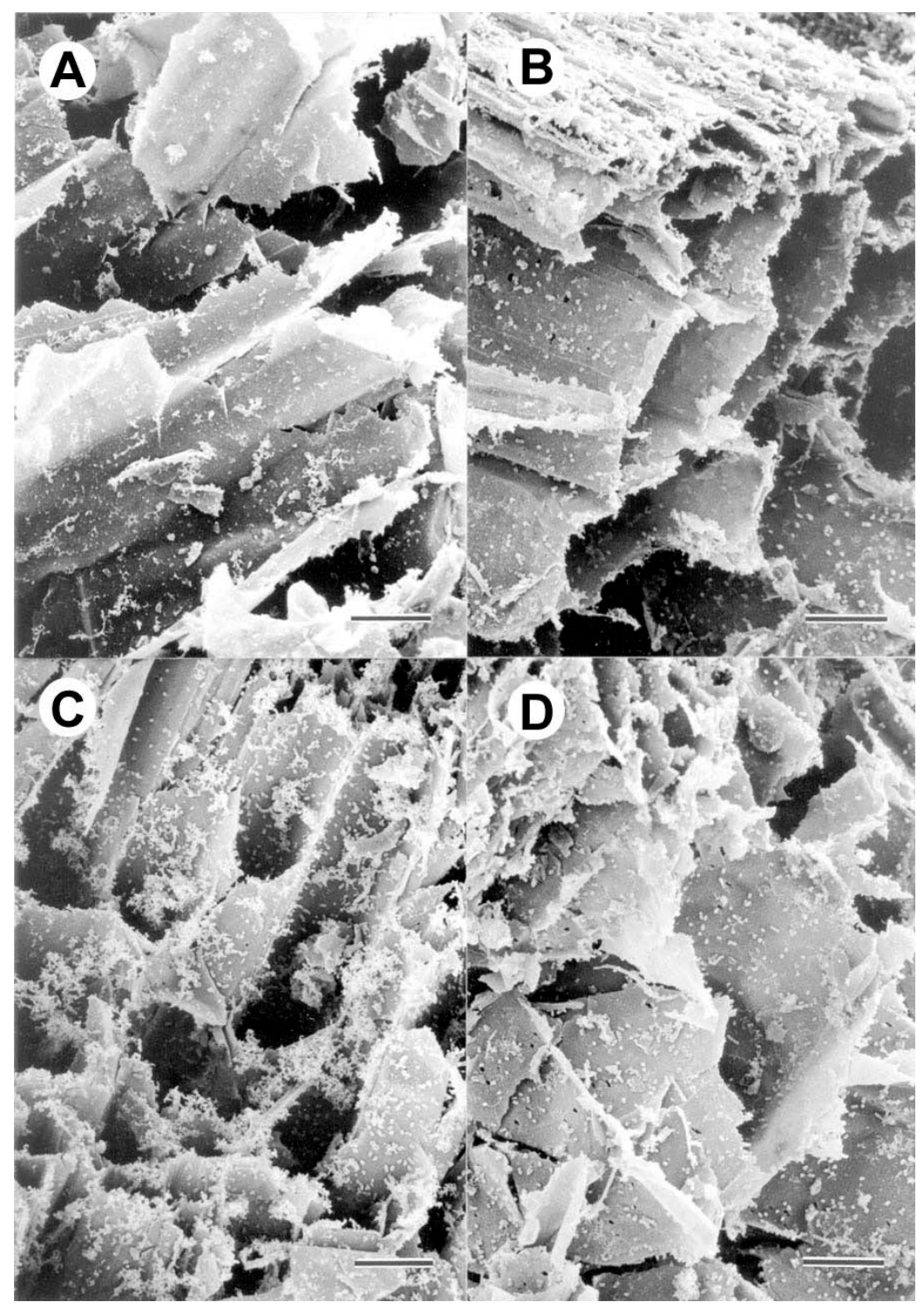

Figure 2. Scanning electron micrographs of barley straw incubated for $48 \mathrm{~h}$ with Ruminococcus flavefaciens in the presence of A) no enzyme, B) $28 \mu \mathrm{g} / \mathrm{ml} \beta$-glucanase, C) $280 \mu \mathrm{g} / \mathrm{ml} \beta$-glucanase and D) $280 \mu \mathrm{g} / \mathrm{ml}$ xylanase. Bars = $20 \mu \mathrm{m}$.

Compared to EPW, re-applying the RS (EPW+RS), but not inactivated EFE (EPW+AE) to $\mathrm{S}$ and AS after washing increased DMD $(\mathrm{p}<0.05)$ at all time points, and GP at 4 and $12 \mathrm{~h}$. In contrast, DMD of EPW, EPW+AE and EPW+RS were all lower $(p<0.01)$ than that of $C$ at all incubation time points regardless of straw type.

With $S$, treatment $E$ had higher $(\mathrm{p}<0.05)$ but EPW and $\mathrm{EPW}+\mathrm{AE}$ had lower $(\mathrm{p}<0.01) \mathrm{PAM}^{15} \mathrm{~N}$ than $\mathrm{C}$ at 4 -h incubation, whereas EPW, EPW+AE and EPW+RS all had higher $(\mathrm{p}<0.05) \mathrm{PAM}^{15} \mathrm{~N}$ at 48 -h incubation as compared to C. All preparations had similar PAM ${ }^{15} \mathrm{~N}$ at 12 -h incubation (Table 3). With AS, however, $\mathrm{PAM}^{15} \mathrm{~N}$ was higher $(\mathrm{p}<0.05)$ for E, EP and EPW+RS at $4 \mathrm{~h}$, for $\mathrm{E}$ and $\mathrm{EPW}+\mathrm{RS}$ at $12 \mathrm{~h}$ and for E, EP, EPW, EPW+AE and EPW+RS at $48 \mathrm{~h}$ of incubation as compared to C. Compared with EPW, $\mathrm{PAM}^{15} \mathrm{~N}$ was increased $(\mathrm{p}<0.05)$ by re-applying the RS
$(\mathrm{EPW}+\mathrm{RS})$, but not inactivated $\mathrm{EFE}(\mathrm{EPW}+\mathrm{AE})$ to $\mathrm{S}$ at 4-h incubation, and to AS at 4- and 12-h of incubation.

Concentration of VFA was higher $(p<0.05)$ for EP and EPW+RS at 48-h incubation with $\mathrm{S}$ and for EPW+RS at 12$\mathrm{h}$ with AS and all other treatments had no effect with respect to C (Table 4). With S, fermentation of EPW, $\mathrm{EPW}+\mathrm{AE}$ and $\mathrm{EPE}+\mathrm{RS}$ resulted in a lower $(\mathrm{p}<0.05)$ molar percentage of acetate at 12 - and 48 -h, but higher $(p<0.05)$ levels of propionate at 48-h and butyrate at 4- and 12-h as compared to C. In contrast, with AS, molar percentage of acetate was lower $(\mathrm{p}<0.05)$, but that of propionate was higher $(\mathrm{p}<0.05)$ for EP, EPW, EPW+AE and EPW+RS than that for $\mathrm{C}$ at 12- and 48-h. With AS, molar proportion of butyrate was higher $(\mathrm{p}<0.05)$ for $\mathrm{EPW}, \mathrm{EPW}+\mathrm{AE}$ and $\mathrm{EPW}+\mathrm{RS}$ at 4- and 12-h, E and EP at 12-h and E and EPW+RS at 48-h. Application of EFE to $S$ and AS prior to 
Table 2. Effect of different pre-treatments with exogenous fibrolytic enzymes (EFE) on gas production and in vitro DM disappearance of native (S) and ammoniated (AS) barley straw

\begin{tabular}{|c|c|c|c|c|c|c|c|}
\hline \multirow{2}{*}{\multicolumn{2}{|c|}{ Substrates $^{1}$}} & \multicolumn{3}{|c|}{ Gas production (ml/g DM) } & \multicolumn{3}{|c|}{ In vitro DM disappearance (mg/g) } \\
\hline & & $4 \mathrm{~h}$ & $12 \mathrm{~h}$ & $48 \mathrm{~h}$ & $4 \mathrm{~h}$ & $12 \mathrm{~h}$ & $48 \mathrm{~h}$ \\
\hline \multirow[t]{6}{*}{$\mathrm{S}$} & $\mathrm{C}$ & 8.2 & 24.5 & 120.0 & 60.1 & 128.3 & 370.5 \\
\hline & $\mathrm{E}$ & 14.5 & 29.2 & 132.0 & 82.7 & 155.2 & 396.6 \\
\hline & $\mathrm{EP}$ & 14.5 & 33.1 & 130.4 & 139.0 & 175.0 & 430.2 \\
\hline & EPW & 5.9 & 16.8 & 130.2 & -17.6 & 22.4 & 303.5 \\
\hline & $\mathrm{EPW}+\mathrm{AE}$ & 7.6 & 21.4 & 127.7 & -5.8 & 48.3 & 312.9 \\
\hline & $\mathrm{EPW}+\mathrm{RS}$ & 11.0 & 28.7 & 133.7 & 2.4 & 61.8 & 322.7 \\
\hline \multirow[t]{6}{*}{ AS } & $\mathrm{C}$ & 10.5 & 24.8 & 154.2 & 85.1 & 126.4 & 507.9 \\
\hline & E & 16.5 & 40.9 & 153.6 & 113.4 & 171.1 & 518.7 \\
\hline & EP & 21.1 & 43.4 & 148.8 & 192.8 & 234.2 & 526.9 \\
\hline & EPW & 7.2 & 22.6 & 153.4 & -4.8 & 27.9 & 404.7 \\
\hline & $\mathrm{EPW}+\mathrm{AE}$ & 10.1 & 27.8 & 152.5 & 4.3 & 41.7 & 413.6 \\
\hline & EPW+RS & 21.6 & 40.9 & 159.2 & 42.6 & 96.8 & 439.7 \\
\hline \multicolumn{2}{|c|}{ SEM $^{2}$} & 0.37 & 0.94 & 3.83 & 2.83 & 4.22 & 3.32 \\
\hline
\end{tabular}

${ }^{1} \mathrm{C}$, S or AS without any EFE treatment; E, straw applied with EFE; EP, straw applied EFE and pre-hydrolyzed for $24 \mathrm{~h}$ before in vitro incubation; EPW, EP washed with water to remove soluble hydrolyzed products (i.e. reducing sugars, phenolic compounds, etc); EPW+AE, EPW treated with autoclaved EFE; EPW+RS, EPW added reducing sugars to the same level as that of in EP.

${ }^{2} \mathrm{SEM}=$ Standard error of means.

incubation with mixed rumen microbes did not affect molar percentage of the major VFAs or the acetate:propionate ratio with the exception that the molar percentage of butyrate was increased $(\mathrm{p}<0.05)$ at 12 - and 48 -h incubation with AS. Acetate:propionate ratio was lower $(\mathrm{p}<0.05)$ for

Table 3. Effect of different pre-treatments with exogenous fibrolytic enzymes (EFE) on the incorporation of ${ }^{15} \mathrm{~N}$ into feed particle associated microbial $\mathrm{N}$ in the in vitro ruminal fermentation of native (S) and ammoniated (AS) barley straw

\begin{tabular}{llrrr}
\hline \multirow{2}{*}{ Substrates $^{1}$} & \multicolumn{3}{c}{${ }^{15} \mathrm{~N} \mu \mathrm{g} / \mathrm{g}$ residual DM } \\
\cline { 3 - 5 } S & C & $4 \mathrm{~h}$ & $12 \mathrm{~h}$ & $48 \mathrm{~h}$ \\
\hline & E & 34.2 & 103.4 & 375.0 \\
& EP & 54.1 & 106.8 & 375.2 \\
& EPW & 36.2 & 99.6 & 385.3 \\
& EPW+AE & 18.5 & 101.0 & 425.2 \\
& EPW+RS & 23.0 & 105.6 & 414.0 \\
AS C & 32.0 & 119.2 & 416.1 \\
& E & 31.3 & 128.8 & 463.1 \\
& EP & 64.4 & 157.7 & 499.8 \\
& EPW & 55.6 & 126.9 & 534.0 \\
& EPW+AE & 30.7 & 126.3 & 595.2 \\
& EPW+RS & 34.6 & 145.6 & 595.0 \\
SEM $^{2}$ & 62.7 & 180.9 & 581.4 \\
\hline
\end{tabular}

\footnotetext{
${ }^{1}$ C, S or AS without any EFE treatment; E, straw applied with EFE; EP, straw applied EFE and pre-hydrolyzed for $24 \mathrm{~h}$ before in vitro incubation; EPW, EP washed with water to remove soluble hydrolyzed products (i.e. reducing sugars, phenolic compounds, etc); EPW+AE, EPW treated with autoclaved EFE; EPW+RS, EPW added reducing sugars to the same level as that of in EP.

${ }^{2} \mathrm{SEM}=$ Standard error of means.
}

EP, EPW, EPW+AE and EPW+RS than C at 12- and 48-but not at 4-h with both $S$ and AS.

\section{DISCUSSION}

\section{Effects of EFE on NDF digestion by $F$. succinogenes and R. flavefaciens}

The greater NDF disappearance of barley straw and alfalfa hay incubated with EFE, F. succinogenes or $R$. flavefaciens, than that of control (no EFE and bacteria) demonstrates that all of them have the independent capacity to digest barley straw and alfalfa hay, although the extent of this degradation by $R$. flavefaciens appeared to be greater than by F. succinogenes. This observation is consistent with the reported by other researchers (Collings and Yokoyama, 1980; Saluzzi et al., 1993). Studies have also shown that strains of $R$. flavefaciens have the ability to degrade noncellulosic polysaccharide components of plant cell walls because they produce a variety of other polysaccharidases including xylanase and pectinase (Flint et al., 1989; Erfle and Teather, 1991). This capacity may account for the ability of $R$. flavefaciens to digest more NDF from alfalfa than F. succinogenes. The ability of these two bacteria to degrade NDF depended on both substrate type and the level of EFE applied. The only synergistic effect of EFE on NDF digestion by $F$. succinogenes was observed with barley straw treated with $28 \mu \mathrm{g} / \mathrm{ml}$ of EFE. The EFE used in this study contained multiple polysaccharide hydrolases including xylanase, $\beta$-glucanase, carboxymethylcellulase and amylase activities (Wang et al., 2003). Our preliminary study showed that autoclaved EFE (enzymatic activities 
Table 4. Effect of different pre-treatments with exogenous fibrolytic enzymes (EFE) on the VFA in vitro ruminal fermentation of native (S) and ammoniated (AS) barley straw

\begin{tabular}{|c|c|c|c|c|c|c|c|c|c|c|c|c|c|c|c|c|}
\hline \multicolumn{2}{|c|}{ Substrates $^{1}$} & \multicolumn{3}{|c|}{ Total VFA (mM) } & \multicolumn{3}{|c|}{$\begin{array}{l}\text { Acetate (A) } \\
\mathrm{mol} / 100 \mathrm{~mol}\end{array}$} & \multicolumn{3}{|c|}{$\begin{array}{c}\text { Propionate (P) } \\
\mathrm{mol} / 100 \mathrm{~mol}\end{array}$} & \multicolumn{3}{|c|}{$\begin{array}{c}\text { Butyrate } \\
\mathrm{mol} / 100 \mathrm{~mol}\end{array}$} & \multicolumn{3}{|c|}{ A:P } \\
\hline & & 4 & 12 & 48 & 4 & 12 & 48 & 4 & 12 & 48 & 4 & 12 & 48 & 4 & 12 & 48 \\
\hline \multirow[t]{6}{*}{ S } & $\mathrm{C}$ & 36.8 & 48.3 & 79.7 & 69.7 & 71.7 & 64.0 & 17.9 & 17.8 & 25.4 & 6.1 & 5.5 & 7.3 & 3.89 & 4.02 & 2.52 \\
\hline & $\mathrm{E}$ & 35.5 & 44.6 & 95.7 & 71.0 & 70.7 & 64.2 & 17.9 & 17.7 & 25.3 & 5.8 & 6.5 & 7.4 & 3.98 & 3.99 & 2.54 \\
\hline & EP & 41.4 & 43.6 & 109.4 & 70.3 & 68.7 & 63.4 & 18.0 & 20.3 & 26.4 & 6.4 & 6.7 & 7.3 & 3.91 & 3.39 & 2.40 \\
\hline & EPW & 34.2 & 40.0 & 92.2 & 68.9 & 68.2 & 60.6 & 16.8 & 19.4 & 29.6 & 7.2 & 6.7 & 7.0 & 4.09 & 3.53 & 2.04 \\
\hline & $\mathrm{EPW}+\mathrm{AE}$ & 34.9 & 42.4 & 96.3 & 68.6 & 67.1 & 60.5 & 17.2 & 19.9 & 29.6 & 7.2 & 7.1 & 7.1 & 3.98 & 3.37 & 2.05 \\
\hline & EPW+RS & 40.4 & 37.6 & 97.5 & 68.9 & 67.3 & 60.9 & 17.9 & 20.4 & 29.1 & 7.2 & 7.2 & 7.2 & 3.84 & 3.30 & 2.09 \\
\hline \multirow[t]{6}{*}{ AS } & $\mathrm{C}$ & 39.6 & 41.8 & 128.7 & 72.2 & 73.5 & 64.5 & 17.0 & 17.1 & 26.6 & 5.4 & 5.1 & 6.4 & 4.26 & 4.30 & 2.43 \\
\hline & E & 43.8 & 57.7 & 127.4 & 71.6 & 71.2 & 63.1 & 17.8 & 18.0 & 26.9 & 5.8 & 6.7 & 7.4 & 4.02 & 3.96 & 2.35 \\
\hline & EP & 49.2 & 60.3 & 119.9 & 67.1 & 69.0 & 61.4 & 21.9 & 20.3 & 28.5 & 6.2 & 6.6 & 7.3 & 3.08 & 3.41 & 2.15 \\
\hline & EPW & 33.6 & 37.7 & 113.0 & 69.8 & 67.8 & 57.9 & 16.4 & 19.6 & 32.9 & 7.0 & 6.9 & 6.6 & 4.25 & 3.46 & 1.76 \\
\hline & $\mathrm{EPW}+\mathrm{AE}$ & 38.1 & 46.8 & 123.2 & 69.6 & 66.6 & 58.0 & 17.1 & 20.8 & 32.9 & 7.0 & 7.1 & 6.7 & 4.07 & 3.20 & 1.76 \\
\hline & EPW+RS & 38.9 & 61.8 & 118.3 & 69.1 & 63.7 & 57.9 & 17.5 & 25.4 & 32.4 & 7.8 & 7.5 & 7.2 & 4.16 & 2.53 & 1.79 \\
\hline \multicolumn{2}{|c|}{ SEM $^{2}$} & 3.19 & 3.70 & 3.44 & 0.97 & 0.65 & 0.55 & 0.96 & 0.45 & 0.27 & 0.21 & 0.22 & 0.19 & 0.302 & 0.082 & 0.036 \\
\hline
\end{tabular}

${ }^{1}$ C, S or AS without any EFE treatment; E, straw applied with EFE; EP, straw applied EFE and pre-hydrolyzed for $24 \mathrm{~h}$ before in vitro incubation; EPW, $\mathrm{EP}$ washed with water to remove soluble hydrolyzed products (i.e. reducing sugars, phenolic compounds, etc); EPW+AE, EPW treated with autoclaved EFE; EPW+RS, EPW added reducing sugars to the same level as that of in EP.

${ }^{2} \mathrm{SEM}=$ Standard error of means.

deactivated) did not degrade barley straw and had no effect on the capacity of $F$. succinogenes or $R$. flavefaciens in digest barley straw (unpublished). Differences in the extent to which EFE affect the digestive capacity of cellulolytic bacteria may be due to the physical and chemical characteristics of the substrates, the inherent enzyme profiles of the bacterial strains and the enzyme profile of the EFE products. The lower efficacy of EFE in enhancing $F$. succinogenes ability to digest straw when applied at 280 $\mu \mathrm{g} / \mathrm{ml}$ as compared to $28 \mu \mathrm{g} / \mathrm{ml}$ may reflect the phenomenon that excess EFE masks adhesion sites for cellulolytic bacteria and thus reduces the extent of microbial colonization, a known perquisite for plant cell wall digestion (McAllister et al., 1994). Morgavi et al. (2004) also observed a reduction of $F$. succinogenes attachment to alfalfa and corn silage when EFE was applied at a high dosage.

Microbial digestion of recalcitrant plant cell wall involves microbial colonization of the feed particles and the integrated action of multiple enzymatic activities depending on the physical and chemical composition of the plant cell wall. It is generally recognized that straws contain greater proportions of cellulose, hemicellulose (xylane) and lignin as compared to alfalfa hay. Bhat et al. (1990) showed that $R$. flavefaciens and F. succinogenes have separate and specific adhesion sites on barley straw. The EFE used in this study enhanced $F$. succinogenes capacity to degrade straw to a greater extent than it did to $R$. flavefaciens, suggesting that enzyme profiles of EFE were more complementary with that of $F$. succinogenes than with $R$. flavefaciens in the digestion of barley straw. With alfalfa hay treated with EFE at the rate of $280 \mu \mathrm{g} / \mathrm{ml}$, NDF degradation by $R$. flavefaciens was greater than $F$. succinogenes. Pre-treatment of alfalfa hay with an EFE product similar to that used in our study also failed to stimulate adherence of $F$. succinogenes (Morgavi et al., 2004). With mixed rumen bacteria, Jalilvand et al. (2008) suggested that EFE were more effective in promoting digestion of higher fibre roughages such as wheat straw as compared to that of alfalfa hay and corn silage. In contrast, Gallardo et al. (2010) showed greater effect of EFE on the digestion of alfalfa hay than straw. The discrepancy among these studies is likely due to the difference in the both the types and activities of enzyme within EFE products. Eun et al. (2007) indicated that a high application level of xylanase was detrimental to the digestion of corn silage by mixed rumen microbial populations and suggested that an ideal ratio of endoglucanase and xylanase is needed to enhance the effectiveness of EFE.

\section{Effects of EFE on microbial colonization and straw digestion by mixed rumen bacteria}

Applying EFE to barley straw prior to incubation increased bacterial colonization of substrate at $4 \mathrm{~h}$ but not at 12 or $48 \mathrm{~h}$ of incubation, indicating that EFE increased the initial rate but not the extent of microbial colonization. This is consistent with previous studies in both our (Wang et al., 2001; 2004) and other laboratories (Varel et al., 1993; Feng et al., 1996). Wang et al. (2004) proposed that the currently available EFE products have limited activity to cleave the esterified bonds within phenolic compounds-mediated lignin-carbohydrate complexes (PC-LCC) which is a key 
barrier to the microbial colonization and digestion of plant cell walls. The increased initial digestion rate by $\mathrm{E}$ is likely due to the release of RS that promote microbial growth and colonization of feed particles, a possibility that is supported by the fact that direct addition of RS to straw increased ${ }^{15} \mathrm{~N}$ PAMN at $4 \mathrm{~h}$, but not at $12-$ or 48 -h incubation.

The lower ${ }^{15} \mathrm{~N}$-PAMN observed with EP than with $\mathrm{E}$ at 4-h, but not at 12- or 48-h incubation suggests that extensive pre-ruminal hydrolysis by EFE reduces initial bacterial colonization. It is likely that extensive EFE activity could lead to accumulation of indigestible PC-LCC on the feed surface thereby inhibiting the attachment of ruminal microbes (Hartley and Akin, 1989; Martin and Blake, 1989). Wang et al. (2004) found that phenolic compound were concentrated in barley straw treated with EFE. It has been proposed that EFE might compete with rumen microbia for reaction sites on the substrate (Beauchemin et al., 2003). The lower initial ${ }^{15} \mathrm{~N}$-PAMN with substrate EPW that was washed after EFE hydrolysis to remove soluble products and EFE than with $\mathrm{E}$ or $\mathrm{C}$ also supports the hypothesis that accumulation of PC-LCC on the surface of barley straw slowed the rate of bacterial attachment.

Alkali treatment (such as with $\mathrm{NaOH}$ or $\mathrm{NH}_{3}$ ) cleaves esterified bonds within the lignin-carbohydrate complex, reducing the physical enmeshment of cellulose and solubilising phenolic compounds and, consequently, facilitating enzyme access (Chesson, 1982; Fahey et al., 1993) and microbial colonization of plant cell walls (Kerley et al., 1985). Wang et al. (2004) first reported synergistic effects between EFE and alkali pre-treatment in microbial straw digestion, a result confirmed by Eun et al. (2006). The results obtained from the present study were consistent with these reports; however, the synergistic effect observed in this study was not as great as previously reported (Wang et al., 2004; Eun et al., 2006). This may be due to the short duration of ammoniation employed in the current experiment, a factor that may have limited the hydrolysis of ester linkages in PC-LCC and thereby limited the access of EFE to hydrolyzable carbohydrates. Further study is needed to define the optimal alkali-pre-treatment condition for the maximum synergistic alkali×EFE interaction in straw digestion.

An interesting observation of this study was that although EFE treatments had no effect on VFA production and profiles, the ruminal fermentation of washed substrates (EPW treatments) after extensive EFE hydrolysis produced VFA with a reduced ratio of acetate:propionate at 12 and $48 \mathrm{~h}$ of incubation for both untreated and ammoniated barley straw. The reason for this phenomenon is not known. The materials washed off straw after EFE hydrolysis were water soluble compounds. Among these, RS are unlikely to have contributed to this observation since adding them back did not change the trend. Further research to identify these compounds may offer alternative way to improve feed efficiency of these feeds.

Exogenous fibrolytic enzymes included in the incubation medium showed potential to improve fibre digestion by cellulolytic ruminal bacteria. However, their efficacy was dependent on substrate, bacterial species and rate of application. Limited EFE hydrolysis prior to ruminal incubation may promote microbial growth by increasing the availability of RS without the accumulation of substantial amounts of PC-LCC at the feed surface. The combination of alkali pre-treatment and EFE synergistically improved ruminal microbial digestion of straw, but the optimal conditions for the synergistic effect need to be defined.

\section{ACKNOWLEDGMENTS}

The study was supported in part by AAFC peer review projects program and the Genozymes project which is a cooperative program supported by Genome Canada, Genome Alberta and Genome Quebec. The authors gratefully acknowledge the technical assistance of $\mathrm{Z}$. Xu, Z. Matic and K. Munns. This is LRC contribution 38711023.

\section{REFERENCES}

Bae, H. D., T. McAllister, J. Yanke, K. J. Cheng and A. D. Muir. 1993. Effects of condensed tannins on endoglucanase activity and filter paper digestion by Fibrobacter succinogenes S85. Appl. Environ. Microbiol. 59:2132-2138.

Beauchemin, K. A., D. Colombatto, D. P. Morgavi and W. Z. Yang. 2003. Use of exogenous fibrolytic enzymes to improve feed utilization by ruminants. J. Anim. Sci. 81:E37-E47.

Bhat, S., R. J. Wallace and E. R. Orskov. 1990. Adhesion of cellulolytic ruminal bacteria to barley straw. Appl. Environ. Microbiol. 56:2698-2703.

CCAC. 1993. Canadian Council of Animal Care. Guide to the care and use of experimental animals, CCAC, Ottawa, ON.

Chesson, A., C. S. Stewaert and R. J. Wallace. 1982. Influence of plant phenolic acids on growth and cellulolytic activity of rumen bacteria. Appl. Environ. Microbiol. 44:597-603.

Collins, G. F. and M. T. Yokoyama. 1980. Gas-liquid chromatography for evaluating polysaccharide degradation by Ruminococcus flavefaciens C94 and Bacteroides succinogenes S85. Appl. Environ. Microbiol. 9:566-571.

Eun, J.-S., K. A. Beachemin, S. H. Hong and M. W. Bauer. 2006. Exogenous enzymes added to untreated or ammoniated rice straw: Effects on in vitro fermentation characteristics and degradability. Anim. Feed Sci. Technol. 131:86-101.

Eun, J.-S., K. A. Beauchemin and H. Schulze. 2007. Use of exogenous fibrolytic enzymes to enhance in vitro fermentation of alfalfa hay and corn silage. J. Dairy Sci. 90:1440-1451.

Erfle, J. D. and R. M. Teather. 1991. Isolation and properties of a (1,3)-p-D-glucanase from Ruminococcus flavefaciens. Appl. Environ. Microbiol. 57:122-129.

Feng, P., C. W. Hunt, G. T. Pritchard and W. E. Julien. 1996. Effect 
of enzyme preparations on in situ and in vitro degradation and in vivo digestive characteristics of mature cool-season grass forage in beef steers. J. Anim. Sci. 74:1349-1357.

Fahey, G. C., L. D. Bourquin, E. C. Titgemeyer and D. G. Atwell. 1993. Postharvest treatment of fibrous feedstuffs to improve their nutritive value. In: Forage Cell Wall Structure and Digestibility (Ed. H. G. Jung, D. R. Buxton, R. D. Hatfield, and J. Ralph). American Society of Agronomy, Inc., Crop Science Society of America, Inc., Soil Science Society of America, Inc., Madison, WI. pp. 715-766.

Flint, H. J., C. A. McPherson and J. Bisset. 1989. Molecular cloning of genes from Ruminococcus flavefaciens encoding xylanase and 1(1-3,1-4) glucanase activities. Appl. Environ. Microbiol. 55:1230-1233.

Gado, H. M., A. Z. M. Salem, H. P. Robinson and M. Hassan. 2009. Influence of exogenous enzymes on nutrient digestibility, extent of ruminal fermentation as well as milk production and composition in dairy cows. Anim. Feed Sci. Technol. 154:3646.

Gallardo, I., R. Bárcena, J. M. Pinos-Rodríguez, M. Cobos, L. Carreón and M. E. Ortega. 2010. Influence of exogenous fibrolytic enzymes on in vitro and in sacco degradation of forages for ruminants. Italian J. Anim. Sci. 9:34-38.

Giraldo, L. A., M. L. Tejido, M. J. Ranilla, S. Ramos and M. D. Carro. 2008. Influence of direct-fed fibrolytic enzymes on diet digestibility and ruminal activity in sheep fed a grass haybased diet. J. Anim. Sci. 86. 86:1617-1623.

Hartley, R. D. and D. E. Akin. 1989. Effect of forage cell wall phenolic acids and derivatives on rumen microflora. J. Sci. Food Agric. 49:405-411.

Jalilvand, G., N. E. Odongo, S. Lopez, A. Naserian, R. Valizadeh, S. F. Eftekhar, E. Kebreab and J. France. 2008. Effects of different levels of an enzyme mixtures on in vitro gas production parameters of contrasting forage. Anim. Feed Sci. Technol. 146:289-301.

Kerley, M. S., G. C. Fahey, L. L. Berger, J. M. Gould and F. L. Baker. 1985. Alkaline hydrogen peroxide treatment unlocks energy in agricultural by-products. Science 230:820-822.

Martin, S. A. and G. G. Blake. 1989. Effects of phenolic compounds on a commercial hemicellulase and two cellulases. Nutr. Reprod. Int. 40:685-693.

McAllister, T. A., H. D. Bae, G. A. Jones and K.-J. Cheng. 1994. Microbial attachment and feed digestion in the rumen. J. Anim. Sci. 72:3004-3018.

McAllister, T. A., A. N. Hristov, K. A. Beauchemin, L. M. Rode and K. J. Cheng. 2001. Enzymes in ruminant diets. In: Enzymes in Farm Animal Nutrition (Ed. M. R. Bedford and G. G. Partridge). CABI Publishing, CAB International, UK. pp. 273-298.
Menk, K. H., L. Raab, A. Salewski, H. Steingass, D. Fritz and W. Scneider. 1979. The estimation of digestibility and metabolisable energy content of ruminant feedstuffs from the gas production when they incubated with rumen liquor in vitro. J. Agric. Sci. 93:217-222.

Morgavi, D. P., K. A. Beauchemin, V. L. Nsereko, L. M. Rode, T. A. McAllister and Y. Wang. 2004. Trichoderma enzymes promote Fibrobacter succinogenes S85 adhesion to, and degradation of, complex substrate but not pure cellulose. J. Sci. Food Agric. 84:1083-1090.

Scott, H. W. and B. A. Dehority. 1965. Vitamin requirements of several cellulolytic rumen bacteria. J. Bacteriol. 89:1169-1175.

SAS. 2007. User's Guide: Statistics, Version 9.6 ${ }^{\text {th }}$ Edition. 2007. SAS Inst., Inc., Cary, NC.

Saluzzi, L., A. Smith and C. S. Stewart. 1993. Analysis of bacterial phospholipid markers and plant monosaccharides during forage degradation by Ruminococcus flavefaciens and Fibrobacter succinogenes in co-culture. J. Gen. Microbiol. 139:2865.

Van Soest, P. J., J. B. Robertson and B. A. Lewis. 1991. Methods of dietary fiber, neutral detergent fiber and nonstarch polysaccharides in relation to animal nutrition. J. Dairy Sci. 74:3583-3597.

Varel, V. H., K. K. Kreikemeier, H. G. Jung and R. D. Hatfield. 1993. In vitro stimulation of forage fiber degradation by ruminal microorganisms with Aspergillus oryzae fermentation extract. Appl. Environ. Microbiol. 59:3171-3176.

Wang, Y., T. A. McAllister, L. M. Rode, K. A. Beauchemin, D. P. Morgavi, V. L. Nsereko, A. D. Iwaasa and W. Yang. 2001. Effect of enzymes supplementation on the ruminal fermentation and microbial protein synthesis in Rusitec. Br. J. Nutr. 85:325-332.

Wang, Y., T. A. McAllister, L. M. Rode, K. A. Beauchemin, D. P. Morgavi, V. L. Nsereko, A. D. Iwaasa and W. Yang. 2002. Effect of exogenous fibrolytic enzymes on epiphytic microbial populations and in vitro silage digestion. J. Sci. Food Agric. 82:760-768.

Wang, Y., T. A. McAllister, J. Baah, R. Wilde, K. A. Beauchemin, L. M. Rode, J. A. Shelford, G. Kamande and K.-J. Cheng. 2003. Effects of Tween 80 on in vitro fermentation of silages and interactive effects of Tween 80, monensin and exogenous fibrolytic enzymes on growth performance by feedlot cattle. Asian-Aust. J. Anim. Sci. 16:968-978.

Wang, Y., B. M. Spratling, D. R. Wiedmeier and T. A. McAllister. 2004. Effect of alkali pre-treatment of wheat straw on the efficacy of exogenous fibrolytic enzymes. J. Anim. Sci. 82:198-208.

Windham, W. R. and D. E. Akin. 1984. Rumen fungi and forage fiber degradation. Appl. Environ. Microbiol. 48:473-476. 